RACAR : Revue d'art canadienne

Canadian Art Review

\title{
Speculations on the Introduction and Role of Alexemata in Doric Temple Architecture
}

\section{John G. Hatch}

Volume 22, numéro 1-2, 1995

URI : https://id.erudit.org/iderudit/1072509ar

DOI : https://doi.org/10.7202/1072509ar

Aller au sommaire du numéro

\section{Éditeur(s)}

UAAC-AAUC (University Art Association of Canada | Association d'art des universités du Canada)

\section{ISSN}

0315-9906 (imprimé)

1918-4778 (numérique)

Découvrir la revue

\section{Citer cet article}

Hatch, J. G. (1995). Speculations on the Introduction and Role of Alexemata in Doric Temple Architecture. RACAR : Revue d'art canadienne / Canadian Art Review, 22(1-2), 1-6. https://doi.org/10.7202/1072509ar
Résumé de l'article

Le temple d'Apollon à Corinthe (c. 540 av. J.-C.) introduit dans l'architecture dorique l'usage du stylobate incurvé et la récession de l'entrecolonnement des coins. Des théories concernant l'usage de ces « raffinements » ont été incapables d'expliquer comment ces ajustements mineurs pouvaient être tolérés à l'intérieur d'un ordre architectural. Cet article propose une nouvelle lecture de la géométrie qui expliquerait comment ces « raffinements » ou alexemata étaient possibles. Cette interprétation trouve ainsi une double justification dans ses fondements philosophiques pythagoriciens et par son accord avec la logique interne de l'Order dorique.
Tous droits réservés @ UAAC-AAUC (University Art Association of Canada | Association d'art des universités du Canada), 1997
Ce document est protégé par la loi sur le droit d'auteur. L'utilisation des services d'Érudit (y compris la reproduction) est assujettie à sa politique d'utilisation que vous pouvez consulter en ligne.

https://apropos.erudit.org/fr/usagers/politique-dutilisation/ 


\title{
Speculations on the Introduction and Role of Alexemata in Doric Temple Architecture
}

\author{
John G. Hatch, The University of Western Ontario
}

\section{Résumé}

e temple d'Apollon à Corinthe (c. 540 av. J.-C.) introduit dans l'architecture dorique l'usage du stylobate incurvé et la récession de l'entrecolonnement des coins. Des théories concemant l'usage de ces «raffinements» ont été incapables d'expliquer comment ces ajustements mineurs pouvaient être tolérés à l'intérieur d'un ordre architectural. Cet article propose une nouvelle lecture de la géométrie qui expliquerait comment ces «raffinements» ou alexemato étaient possibles. Cette interprétation trouve ainsi une double justification dans ses fondements philosophiques pythagoriciens et par son accord avec la logique interne de l'Order dorique.
Introduction

$T$ he subtle variations found in Greek Doric temples, known as alexemata, have fascinated architectural historians since their "discovery" in the nineteenth century. ${ }^{1}$ These minute adjustments in the inclination of columns, curvature of the stylobate, recession of metope widths, etc., were first introduced at the Temple of Apollo in Corinth (ca. 540 B.C.) and became a regular feature of temple construction, culminating in their encyclopedic use on the Parthenon (447-432 B.C.). A number of theories have emerged to explain these "refinements," the most famous of which was advanced by Vitruvius who suggested that alexemata were a necessary device to counter the optical distortions engendered by such large structures. ${ }^{2}$ Unfortunately, most of these theories rest on the uneasy dichotomy of introducing apparent distortions into a structure whose care and precision in planning and whose whole elevation is based on a rationality of design which embodies an orderly notion of cause and effect. This paper proposes a simple geometric model that shows how alexemata may in fact be logically derived refinements consistent with the rationale underlying the Doric Order as a whole.

Alexemato: A Model

The Temple of Apollo at Corinth is the first known Doric structure to use alexemata. Its columns stood on a convex stylobate whose curvature extends down to rock cuttings below the foundation. ${ }^{3}$ The regularity of this curvature and the solidity of the foundation upon which it rests indicate that its presence was intentional and not simply due to a sagging of the ground resulting from earthquakes or settling. The integration of such a curvature into a relatively large temple structure would have presented a myriad of design and technical problems. Its introduction must have necessitated a preliminary design and a better overall organization of construction than was required in the earlier, formative stages of the Greek Doric temple. It would be difficult then to assign to the architect(s) of the Temple of Apollo at Corinth the traditional designation of a master craftsman with no real responsibility for the design of buildings. Rather, he falls more in line with Plato's definition of architekon, a director of workmen who contributes both practical and theoretical knowledge. ${ }^{4}$ This would not be unusual given that by the mid-sixth century B.C., when we first find recorded the names of temple architects, the status of the Greek architect had risen considerably. The most notable example is Theodoros of Samos, an engineer who worked on the Temple of Hera at Samos (mid-sixth century B.C.). The fact that Theodoros was an engineer suggests his involvement in the design and planning of the Temple of Hera; this is further supported by Vitruvius' mention of Theodoros having authored an architectural treatise dealing with that structure. Vitruvius also notes that the architects Chersiphron and Metagenes wrote a treatise dealing with the Temple of Artemis at Ephesus (second half of the sixth century B.C.). ${ }^{5}$ Such treatises certainly contributed to the standardization of both the Doric and Ionic Orders. Unfortunately, our knowledge of sixth-century B.C. Doric temple construction is poor, and we must resort to a hypothetical recounting of design and building procedures based on the information we do possess of the fifth and fourth centuries B.C. Clearly some caution must be taken, but considering the relative consistency of the Doric Order, such an attempt may prove quite fruitful.

Admitting the architect as designer, the question remains as to the nature of the designs and particularly how they dealt with the implementation of alexemata. Unfortunately, there are no records of elevation plans for the Temple of Apollo at Corinth. ${ }^{6}$ Yet, considering the particular problems involved in using a curved stylobate, its effects could only be conceived of in the form of a preliminary elevation plan. Such a design possibly resembled that depicted in figure 1, where we find an exaggerated view of the stylobate's curvature in the form of the arc of a circle. The centre of the circle is identified as point $A$. From point A, we generate 6 radii which are labelled B, C, D, E, F and 
figure I. Exaggerated view of stylobate curvature (Drawing: author).

$G$, and whose angles are equal, i.e. angle $a_{b c}=$ $a_{c d}=a_{d e}=a_{e f}=a_{f g}$. Extending each radius beyond the circumference, we thus produce six columns upon our theoretical temple elevation, paralleling the six columns used on the front and back of the Temple of Apollo. ${ }^{7}$

Figure 1, as yet, presents nothing unusual. Some authors might object to the use of a circle rather than a parabola, yet a number of facts seem to preclude the use of the latter. ${ }^{8}$ Firstly, a circle is a much simpler geometric form to handle than a parabola (especially when one considers the incremental measurements involved in calculating the degree of variation alexemata entail). Secondly, concentric curvatures (stylobate and entablature) are used at the Parthenon, and their interrelationship is easier to determine

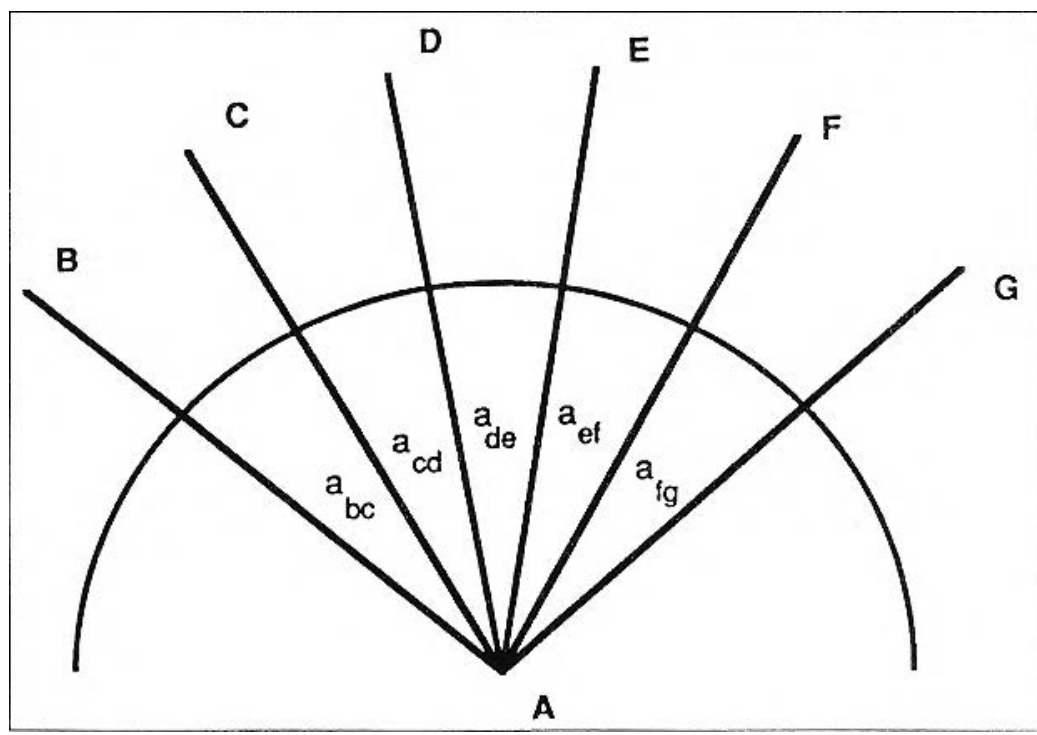
in terms of a circle than a parabola, given that a common focal point must be found for the latter: a focal point that can only be determined through the use of a mathematical formula which was as yet unknown. Thirdly, where the use of a conic section (other than a circle) was believed to be involved in the design of Ionic column bases, Lothar Haselberger has uncovered drawings at the Temple of Apollo at Didyma (ca. 330 B.C.) revealing that such column bases were in fact designed through a series of manipulations of circles. ${ }^{?}$ Lastly, it appears more likely that a circle was used since its derivation for an elevation plan could simply have been taken from designs for column flutings: the commonality between the drawing of a column cross-section found at the Temple of Apollo at Didyma and figure 1 suggest such a conclusion. ${ }^{10}$

Returning then to figure 1, the architect of the Temple of Apollo at Corinth had to face an obvious problem, namely the outward slant of the columns toward the corners of the structure. A correction had to be made by giving the columns a slight inward inclination toward the centre of the row of columns. The degree of this correction, however, was not haphazard; the columns were simply redressed perpendicularly to a horizontal line represented by the tangent line $G$ at the top of the semi-circle in figure 2. These redressed columns are labeled $B^{\prime}, C^{\prime}, D^{\prime}, E^{\prime}, F^{\prime}$ and $G^{\prime}$. In this manner, the columns would be perpendicular to the entablature which, in the case of the Temple of Apollo at Corinch, is straight. ${ }^{11}$

As unmomentous as figure 2 appears in correcting the outward slant of the columns, it may explain why the architect at Corinth used a curved stylobate in the first place. By redesigning the elevation along a horizontal line tangent to the curvature of the stylobate, there occurs a gradual

narrowing of intercolumnation as one moves outward from the central column $D$ in figure 2 . Hence the distance between columns B' $C$ ' will be smaller than that between C'D', and therefore $x<y$. Considering the size of the temple and the breadth of the arc of the stylobate, this intercolumnation recession would be barely perceptible near the centre but would become more evident near the corners of the structure. Unfortunately, with only seven columns standing, it is difficult to establish exactly whether the architect of the Temple of Apollo did gradually recede the distance between the columns. What is known for certain, though, is that the intercolumnations at the corners are reduced. ${ }^{12}$

Debates persist over the presence of intercolumnation recession beyond the corner column for a number of Doric temples. This comes as no surprise. As the proposed model illustrated in figure 2 indicates, differences in intercolumnations would be smaller at the centre of a row of columns than near the ends; given the rather incremental recession that does occur at the corners, a consistent intercolumnation recession, especially on the side of a temple, would be extremely difficult to implement on such large structures. ${ }^{13}$

Despite the debates surrounding intercolumnation recession, there is general agreement that the corner recession was introduced in order to handle the so-called angle triglyph problem. In Doric architecture, triglyphs are situated directly above the centre of each column, but this is not possible at the corners. This inherent problem initiated a variety of solutions, but most fall short of conforming to the highly regimented, deterministic unity of the Doric Order. ${ }^{14}$ The architect at Corinth may have decided to devise a theoretical model that could supply at least a logical rationale for the recession of the corner intercolumnation, even though its implementation may have presented 
Figure 2. Exaggerated view of stylobate curvature: adjustment of columns (Drawing: author).

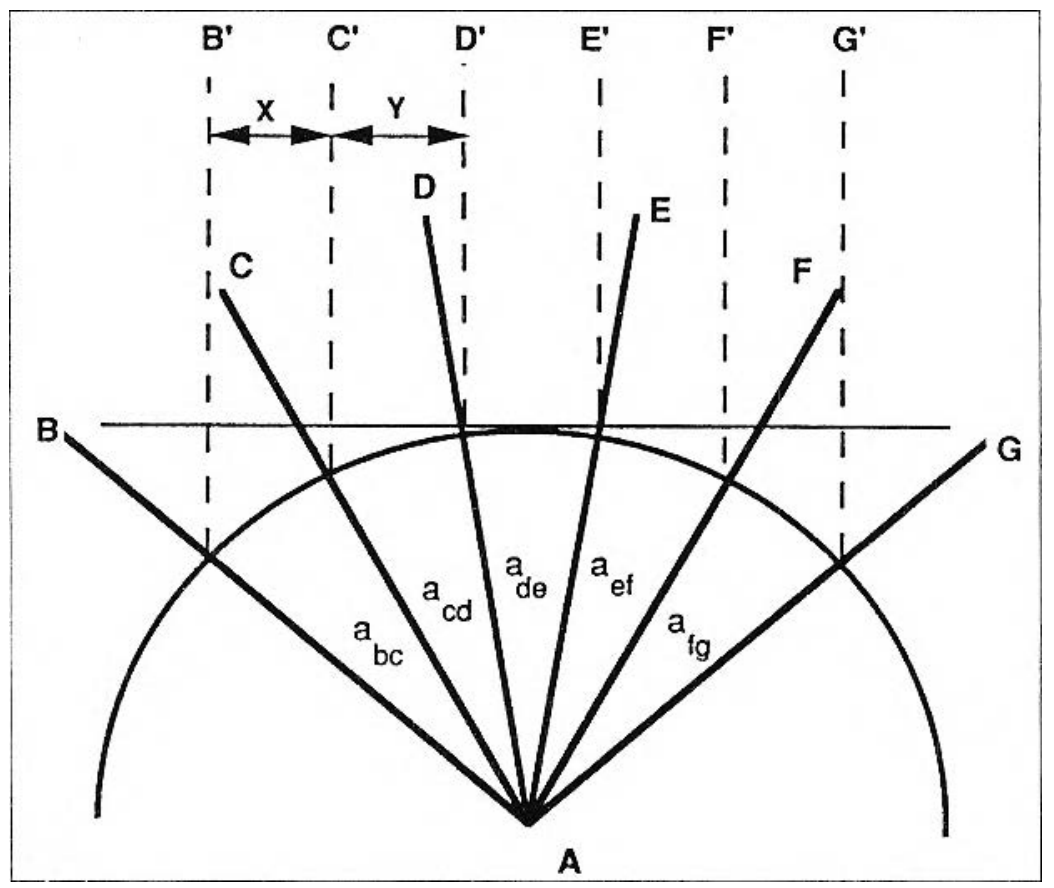

as an intermediary between the human and the divine.

If this interpretation appears far-fetched at first, we must remember that Pythagoras saw the ecstatic contemplation of geometric forms and mathematical laws as the principal link between mortals and the divine. Furthermore, Plutarch records that, for Pythagoras, geometry acts to draw us away from the world of sensory corruption and toward the world of the intellect and the eternal. It is also Pythagoras' concept of theoria that channels religious fervour into intellectual fervour and ritual ecstasy to the ecstasy of discovery, thus establishing mythology and geometry as part of the same indivisible reality. ${ }^{19}$ If we are to seek a philosophical justification for the introduction of alexemata into Doric architecture, Pythagorean thought emerges as a plausible explanation. Sceptics may find fault with such reasoning, but they should bear in mind the particular character of the

numerous difficulties which would only be mastered in the fifth century B.C. The model presented in figure 2 possibly represents that theoretical justification, one which suits the rationality of design that underlies the Doric Order, maintaining the orderly notion of cause and effect ruling Greek architecture.

\section{Alexemoto and Pythagoras}

Where the alexemata model presented in figure 2 (with its juxtaposition of a curved stylobate and horizontal tangent line) was possibly undertaken to justify the intercolumnation recession necessitated by the angle triglyph, there also emerges a possible philosophical/religious justification for the use of this model in Pythagorean thought. ${ }^{15}$ One theory suggests that alexemata were generated in order to produce a certain tension of form, providing a living quality to what would orherwise have been an apparently static design. ${ }^{16}$ Such an interpretation may be allied to Pythagoras' concept of armonia which itself emerges as a consequence of a tension between opposites. ${ }^{17}$ According to Aristotle, Pythagoras recorded ten such opposites, one of which is the opposition between "curved" and "straight." 18 Furthermore, these two opposing elements carry an apparent symbolic significance where the "straight" echoes the realm of Olympus (the gods), and the "curved" pertains to the lesser realms of humanity and nature. It would seem self-evident that the communion of these two elements finds no better expression than in a Greek temple, a structure which acts
Greek mind, and the more than coincidental fact that the first architectural treatises were written around the same time as the first philosophical prose. ${ }^{20}$

As noted earlier, the most popular theory concerning the function of alexemata is presented by Vitruvius. He believed that such elements as a curved stylobate were used in order to correct the optical distortions that were thought to occur if Doric proportions were strictly applied. ${ }^{21}$ Considering how diluted Vitruvius' sources may have been, it appears that his interpretation may be but a residue of the original Pythagorean justification. Where the notion of geometric armonia in the union of opposites may be the generating factor in the concept of alexemata, a complementary function does arise in the contemplation of geometry as drawing us away from the world of sensory corruption. Thus, some validity may be conceded to Vitruvius' "optical theory," but it should probably be subsumed to the primary idea of armonia between the human and the divine.

\section{Pythagoras and scomilli impores}

The relationship between Pythagorean thought and the in troduction of alexemata at the Temple of Apollo at Corinth may also explain the enigmatic application of the technique of scamilli impares to the curvature of the stylobate. The term was first used by Vitruvius, but he failed to explain what the technique involved. ${ }^{22}$ This has left architectural historians speculating as to the application of scamilli impares. One explanation was supplied by G.P. 
Figure 3. a) Derivation of square numbers from succession of odd numbers. b) Pythagorean number/figure: square of 25. c) Scamilli impares. Construction of stylobate based on Pythagorean odd number/figure (Drawing: author).

Stevens in his 1934 essay "Concerning the Curvature of the

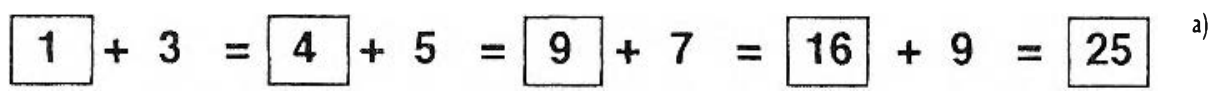
Steps of the Parthenon." 23 Here,

Stevens derived scamilli impares through a skilful manipulation of a parabola. Unfortunately, though the parabola may have been known as a geometric form, its mathematical formulation, which Stevens depends upon extensively, was only discovered in the third century B.C.

The root to solving the problem lies with the meaning
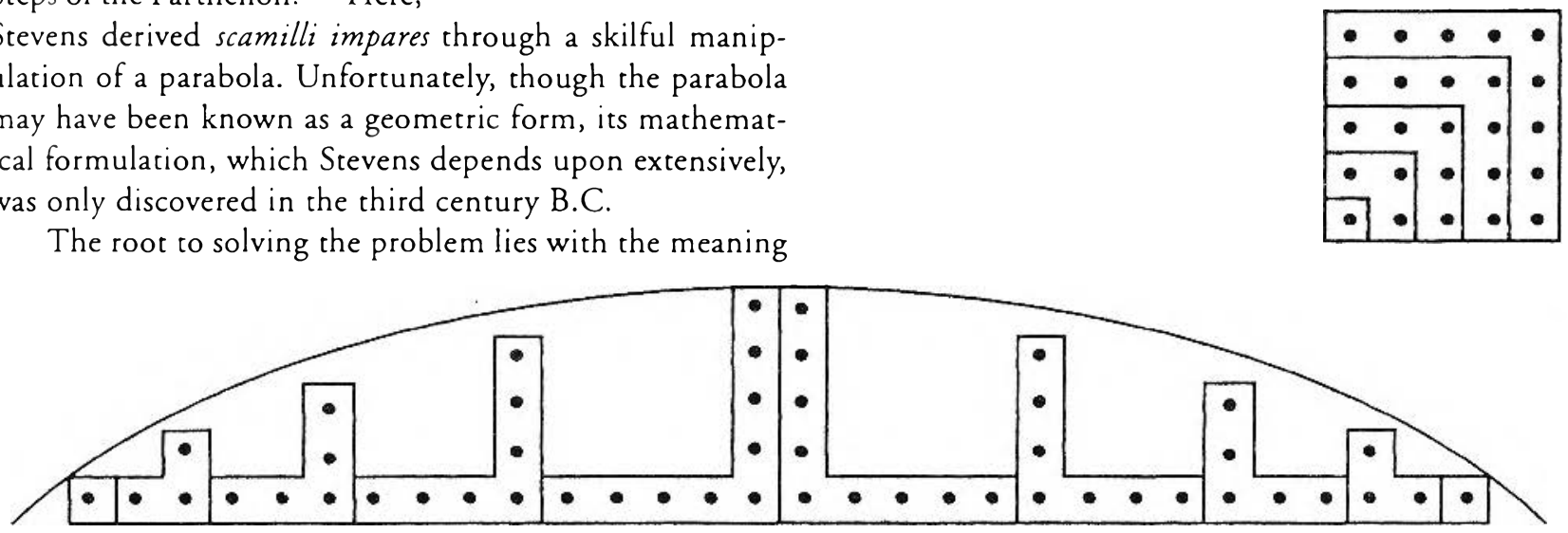

of the words scamilli impares. Scamilli can be defined as meaning "steps," "bench" or "seat;" impares is defined as either "uneven," "unequal" or "odd," as in odd numbers. W.B. Dinsmoor has used the meaning of these two terms in illustrating his reconstruction of the curvature found at the Parthenon by producing a series of odd-numbered steps. ${ }^{24}$ But the words scamilli impares may refer more specifically to Pythagoras' number-shapes, where numbers take on particular forms, allowing for ease of calculation. As a follower of Pythagoras noted: "All things have form, all things are form; and all forms can be defined by numbers." 25 For example, square numbers can be derived from a succession of odd numbers, as illustrated in figure $3 \mathrm{a}$. Their number form would literally take the shape of a square, as shown in figure $3 b$ for the number 25 . Therefore, scamilli impares may simply refer to the slope of a curve composed of a succession of odd number/figures in a series of steps as illustrated in figure $3 c$. This explanation incorporates concisely the meaning of the words scamilli impares, while also suggesting the method of its implementation through the simple use of a "mason's square." 26

This possible incorporation of Pythagorean number theory to the design and construction of the stylobate may seem somewhat simplistic, yet simplicity is the one quality dominating Doric construction. Furthermore, Pythagoras' number theory was permeated by a religious fervour which is difficult for us to conceive of today. None the less, it was a central aspect, as a follower of Pythagoras recorded in the fifth century:

Consider the effects and the nature of number. ...It is great, all-powerful, all-sufficing, the first principle and the guide in life of Gods, of Heaven, of Men. Without it all is without limit, obscure, indiscernable. The nature of number is to be a standard of reference, of guid- ance, and of instruction in every doubs and difficulty. Were it not for number and its nature, nothing that exists would be clear to anybody either in itself or in its relation to other things. ${ }^{27}$

Needless to say, the incorporation of a Pythagorean scamilli impares in a religious structure would not be out of place, particularly in a structure that mediates between the divine and the mortal. As the above passage stresses, number is the guide of both gods and men. Furthermore, this same author concluded the above passage by referring specifically to the arts: "You can observe the power of number exercising itself not only in the affairs of demons and of gods, but in all the acts and thoughts of men, in all handicrafts and in music."

\section{Concluding Remarks}

It is somewhat surprising that so little has been written on the possibility of the Greek temple acting, in part, as a cosmic metaphor. Yet there is considerable evidence to suggest such an interpretation, the least of which is the use of Atlantids as supporting elements in a number of Greek temples found in Italy. The term kosmos itself means order, but it was also used to designate ornamentation, and when Plato describes the creation of the universe/cosmos in the Timaeus, he does not hesitate to use the tools of the architect as a visual metaphor in his description; hence the popular Gothic image of God as architect/geometer. ${ }^{28}$ Pythagoras' predecessor and mentor, Anaximander (ca. 610-540 B.C.), described the earth as suspended in the centre of a cylinder or a stone pillar and the earth's form as concave like the drum of a column. ${ }^{29}$ Pythagoras' own philosophy lends itself well to an architectural language such as the Doric Order. Although my interest in this essay has been to focus 
on the possibility of a Pythagorean rationale for the introduction and implementation of alexemata, there exists a more general correspondence between the Doric Order and Pythagorean thought which has failed to draw the attention of students of Greek temple architecture.

Central to Pythagoras' teachings is the notion of the soul as trapped in the body. ${ }^{30}$ The only way we can free the soul from the demands of the body is through the contemplation of the numerical harmony of the cosmos. ${ }^{31}$ For Pythagoras, this contemplation of the cosmos was both an aesthetic and a divine experience. The aesthetic dimension manifests itself in the realization that the harmony of the cosmos is based on a system of numerical proportions between opposing elements such as odd and even numbers or the straight and the curved. ${ }^{32}$ This aesthetic experience was complemented by the fact that each number up to ten was associated with a particular god, the most important being One, the source of all numbers, which Pythagoras attributed to Apollo. ${ }^{33}$ The arithmetic and proportional unfolding of numbers, primarily from the One to ten, represented for Pythagoras the imposition of limit or order on the unlimited, i.e. the divine structuring of the cosmos. ${ }^{34}$ There is a fascinating link between this idea of numerical unfolding and the rather systematic proportional unfolding of the elevation of a Doric temple which, as Rhys Carpenter first pointed out, functions in terms of a proportional system of 2:1. Thus, for each column of a Doric temple one finds two regulae, 2 triglyphs +2 metopes, 4 mutules, 4 lion'sheads (water drains) and 8 rows of cover-tiles. Carpenter also observes that a system of proportion was, at times, applied to measurements as well. ${ }^{35}$ The fact that this feature of Doric architecture was only first applied with any regularity in the sixth century seems significant.

A final aspect of Pythagoras' teachings may further elucidate our understanding of the rationale behind the application of alexemata at the Temple of Apollo at Corinth. Atrributed to Pythagoras is the idea that the air closest to the earth is unhealthy and sluggish, and all things in it are mortal, while the uppermost air is pure and wholesome with the things found in it immortal and divine. The fact that the alexemata found at the Temple of Apollo are applied below the entablature may be yet another feature, like the opposition between the straight entablature and curved stylobate, reinforcing the notion of the temple as a meeting place between the mortal and the divine. This duality between the upper and lower parts of the structure may be yet another expression of Pythagorean armonia between opposing elements which lies at the basis of the structure of the cosmos.

Unfortunately, as with most of the theories dealing with this period of Greek architecture, there is no firm documentary proof available. All of the past explanations of why alexemata were used, for example, are based purely on circumstantial evidence, as is the case with the model found in figure 2 . That model could possibly be tested against architectural measurements, but whether this can actually be done, given the state of the Temple of Apollo at Corinth, is doubtful. ${ }^{36}$ Nevertheless, the simplicity of the model proposed above, and its logic and religious/philosophical justification, make it a viable alternative and even complementary explanation of the use and implementation of alexemata: complementary in the sense that it does not contradict past interpretations of alexemata. In fact, the interpretations of alexemata as engendering a living quality in a static design, or serving to correct optical distortions, are all elements implicit in the interpretation of alexemata proposed in these pages.

Notes

I would like to express my gratitude to Don Andrus, David Cave, J. Gerard Curtis, Madeline Lennon and Karen Hatch for their many helpful suggestions and criticisms regarding this paper. I must also single out the invaluable assistance provided by the Society of Architectural Historians and the anonymous reader for $R A C A R$.

l Alexemata has been translated by various authors as either "compensations," "betterments," "nicities," "refinements" or "deviations." See J.J. Pollitt, Art and Experience in Classical Greece (Cambridge, 1972), 75; A.W. Lawrence, Greek Architecture, 4th edn (Harmondsworth, 1983), 222-27; and W.H. Goodyear, Greek Refinements (New Haven and London, 1912).

2 For an excellent account of Vitruvius' interpretation, as well as ocher theories on the role of alexemata, see Pollitt, Art and Experience, $75-78$.

3 D.S. Robertson, Handbook of Greek and Roman Architecture, 2nd edn (Cambridge, 1945), 116.

4 J.J. Coulton, Greek Architects at Work (London, 1977), 15.

5 Coulton, Greek Architects, 24.

6 The lack of temple designs may be explained by the circumstances surrounding Lothar Haselberger's accidental discovery of the designs for the Temple of Apollo at Didyma (ca. 330 B.C.) which were published in 1985. Lothar Haselberger, "The Construction Plans from the Temple of Apollo at Didyma," Scientific American (Dec. 1985), 126-32.

7 The curvature at the Temple of Apollo is found on all sides of the structure. W.B. Dinsmoor, The Architecture of Ancient Greece, 3rd edn (New York, 1975), 90.

8 William Bell Dinsmoor is one of the few authors who belicve that stylobate curvatures are based on the arc of a circle rather than some other conic section. Dinsmoor, The Architecture of Ancient Greece, 168. 
9) Haselberger, "Construction Plans," 129.

10 Haselberger, "Construction Plans," 130. There is clearly some danger in using the drawings at Didyma and comparing them to a sixth-century structure, but the fluting designs at Didyma are so elementary that it is doubtful they would have changed much since the sixch cencury.

11 The difficulcies involved in performing this "correction" may explain why the columns used at Corinth are monolithic and devoid of encasis.

12 A gradual intercolumnation recession near the corners has been measured at the Temple of Achena in Syracuse (shortly after 480 B.C.), a structure which has better survived the vagaries of time and shares the same key refinements found at the Temple of Apollo at Corinth (curved stylobate and columns inclining away from the corners). Dinsmoor, The Architecture of Ancient Greece, 108.

13 The Parthenon is one example where there is general agreement on the presence of a gradual recession of intercolumnations on the ends but, as Dinsmoor indicates, little agreement exists in terms of whether this phenomenon also occurs on the sides of the structure. Dinsmoor, The Architecture of Ancient Greece, 108, n. 2 .

14 Rhys Carpenter supplies an excellent account of the highly regimented system involved in Doric construction which qualifies it as an architectural Order. Carpenter, The Esthetic Basis of Greek Art (Bloomington, 1959), 133-38.

15 Pythagoras (ca. 582-500 B.C.) lived at the time of the construction of the Temple of Apollo at Corinth. Although he was a resident first of Samos and then moved to Croton in southern Italy around 530 B.C., the impact of his philosophy as disseminated by his followers extended far beyond these two cities. It is not unreasonable to suggest that Pythagoras' philosophy could have reached Corinth by 540 B.C., given Corinth's importance as a major maritime trading centre.

16 Pollite, Art and Experience, 76-78.

17 Arthur Kocstler, The Sleepwalkers (Harmondsworth, 1964), 29. It should be noted that Pythagoras' notion of a tension of op- posites was also postulated by Anaximenes (ca. 600-550 B.C.) and Heraclitus of Ephesus (floruit ca. 500 B.C.).

18 John M. Robinson, An Introduction to Early Greek Philosophy (Boston, 1968), 119.

19 Koestler, The Sleepwalkers, 37-38.

20 Coulton, Greek Architects, 24.

21 Pollitt, Art and Experience, 75.

22 Vitruvius, The Ten Books on Architecture (New York, 1960), 89 , 155.

23 G.P. Stevens, "Concerning the Curvature of the Steps of the Parthenon," American Journal of Archeology, XXXVIII (1934), 533 42.

24 Dinsmoor, The Architecture of Ancient Greece, 168, fig. 59.

25 Koestler, The Sleepwalkers, 30.

26 Evidence of the use of the mason's square dates back to the beginning of the seventh century B.C. Coulton, Greek Architects, 46.

27 Koestler, The Sleepwalkers, 42.

28 Plato, Timaeus, 33b-34b.

29 Jonathan Barnes, Early Greek Philosophy (Harmondsworth, 1987), 72; and Robinson, Early Greek Philosophy, 29.

30 Robinson, Early Greek Philosophy, 58-59.

31 Robinson, Early Greek Philosophy, 67-68.

32 Robinson, Early Greek Philosophy, 77.

33 Peter Gorman, Pythagoras: A Life (London, 1979), 60, 116, 134.

34 Robinson, Early Greek Philosophy, 73-74.

35 Carpenter, Esthetic Basis, 120-23.

36 Even if exact measurements were available, it might be pointless to try to fit them to any theoretical design since, as David Lindberg notes with regard to Greek astronomy before the Hellenistic period, there was no interest with matching numerical or quantitative values to theoretical/geometric models. David C. Lindberg, The Beginnings of Western Science (Chicago and London, 1992), 94, 98-99. 